\title{
Accumulation of Calcium Crystal in Rat (Rattus norvegicus) Kidney
}

\author{
A'liyatur Rosyidah, Sri Widyarti*, Sri Rahayu \\ Biology Department, Faculty of Mathematics and Natural Sciences, Brawijaya University, Malang, Indonesia
}

\begin{abstract}
The aim of the research was to know the effect of tuber Porang powder (Amorphophallus muelleri) to calcium crystal accumulation on kidneys. The research used 2,5-months-old male rats that were orally given tuber Porang powder from three different locations (Klangon, Sumber Baru, and Sumber Bendo) with doses of $6 \mathrm{mg} / 100 \mathrm{gr} \mathrm{BW} /$ day for 3 months. The distribution of calsium crystal accumulation on kidneys was observed under an Olympus microscope CX 31 at 400x magnification. The data were analysed using ANOVA employing SPSS 16 for Windows. The result of the study showed that consumption of tuber Porang powder induced calcium crystal accumulation in rat kidneys. The use of tuber Porang powder from different locations was found to generate different impacts on the accumulation of calcium crystal. The lowest calcium crystal accumulation in kidneys was the ones given Klangon Porang powder, which was equal to $8,19 \pm 2,17$ spot/ area. In short, the consumption of tuber Porang powder caused the accumulation of crystal calcium in rat kidneys.
\end{abstract}

Keywords: Amorphophallus muelleri, calcium crystal, kidneys

\section{INTRODUCTION}

Porang (Amorphophallus muelleri) is a plant whose tuber having such high amount of glucomanan that is $67 \%$. This plant is normally consumed as an alternative source of carbohydrate because glucomanan is one of carbohydrate derivates [1]. Glucomanan is one of polysaccharide that consists of galactose, glucose, and mannose binding. Glucomanan has several advantages since glucomanan has water insoluble fibers, contains non-fat sugar, contains starch and protein, has complex carbohydrate, is translucent, is gelatinous, does not smell, and can be stored at room temperature for about one year [2]. Besides that Porang also contains calcium oxalate. Consuming food containing high amount of calcium oxalate continuosly will cause kidney stone formation and can lead to a pathological condition known as nephrolithiasis [4,5]. Nephrolithiasis (kidney stones) is one type of kidney disease characterized by the formation of kidney stones in the kidney tubules or renal pelvis, ureter, and / or urinary bladder. Kidney stone formation consists of several stages

\footnotetext{
${ }^{*}$ Corresponding author: Sri Widyarti

Biology Department, Faculty of Mathematics and Natural Sciences, Brawijaya University, Jl. Veteran, Malang, Indonesia 65145

Email: swid@ub.ac.id
}

aggregation and retention within renal tubules [5]. Supersaturation urine may promote crystalisation process, in which urine having high amount of calcium, phosphate, and oxalate causes calcium oxalate crystal formation. In this condition, the oxalate crystal will bind to the renal tubulus cell and generate interaction between both of them [6]. The interaction between renal epithelial cells and calcium oxalate $(\mathrm{CaOx})$ crystal and/or oxalate ions plays an important role in the formation of kidney stone [7]. In these conditions, there is a protein called Oxalate Binding Protein, whose activity will increase by the amount of calcium oxalate in the kidney. This particular protein plays a significant role in the nucleation process. Oxalate Binding Protein will bind oxalate in kidney leading into crystal nucleation [8].

Thus, we need to analyze the effect of long time Porang tuber consumption (for 3 months) especially dealing with calcium crystal accumulation. Different Porang tubers used in this study were taken from different locations; and it was assumed that they would cause different effects on calcium crystal accumulation. The aim of the research was to evaluate the effect of tuber Porang powder (Amorphophallus muelleri) to the accumulation of calcium crystal in rat (Rattus norvegicus) kidneys. 


\section{MATERIALS AND METHODS}

\section{Animal Treatment}

This experiment using male wistar rats at 2.5 month age. These animals were aclimated for 7 days before treatment. In this experiment, Porang; they were taken from three different locationsKlangon, Sumber Baru, and Sumber Bendo. The rats were divided into 4 groups. Group I was used as a control group (not supplemented with Porang tuber powder). Group II, group III, and group IV were given Klangon, Sumber Bendo, Sumber Baru Porang tuber powder, respectively. All of the experiment groups were administered $6 \mathrm{mg} / \mathrm{g} \mathrm{BW} /$ day Porang tuber powder orally for 3 month.

\section{Making Porang Tuber Powder}

There three kind of Porang that use for this experiment that different by location are Sumber Baru, Sumber Bendo, and Klangon. These tubers were maked an chips and were crushed to obtain the powder of tuber. the Porang tuber powder were weighed according tho the dose of each rats and were diluted with $1 \mathrm{~mL}$ warm distilled water.

\section{Detection of Calcium Crystal Accumulation in Kidneys}

The rats were killed by neck dislocation and were sectioned using standard method. The rat kidneys were removed and fixed in $4 \%$ paraformaldehyde. Four micrometers of paraffin section were dewaxed, stained with alizarin red (pH 6.4) for 5 minutes and methyl green 3\% for 2 minutes. These slides were washed thoroughly with distilled water then mounted by ethelan and observe using CX 31 light microscope [9].

\section{Data Analysis}

The data were analyzed using test of variance (ANOVA) technique with $\mathrm{P}<0.05$. Tukey HSD test was used to compare the means. Both tests were conducted using SPSS 16 for Windows.

\section{RESULTS AND DISCUSSION}

The rats given Porang tuber powder developed calcium oxalate accumulation in their kidneys. Calcium crystal accumulation appeared as orange spots after alizarin red staining (Figure 1). Calcium crystal accumulation dominantly occurred in kidney tubules. Accumulation of calcium oxalate generally occurs in kidney tubules, especially in collectivus tubules [10].
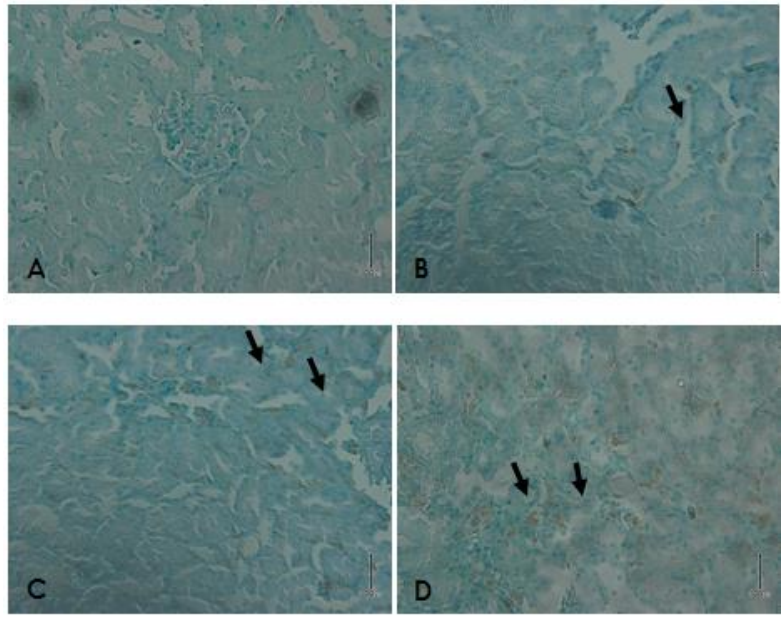

Figure 1. Histology of the rat kidneys with calcium crystal accumulation (a) Control, (b) Klangon, (c) Sumber Bendo, (d) Sumber Baru. (à Crystal Calcium). 1 scale $=300 \mu \mathrm{m}$.

The kidneys from the rats given Porang tuber powder from Sumber Baru, Sumber Bendo, Klangon and the also the kidneys of the control group had an average distribution of calcium crystal accumulation equal to $17.4 \pm 2.28$ spot/ area, $11.9 \pm 2.36 \mathrm{spot} /$ area, $8.19 \pm 2.17 \mathrm{spot} /$ area and $3.17 \pm 0.58$ spot/ area, respectively (Figure 2). The kidneys supplemented with Porang tuber powder were significantly different from the kidneys of the control group $(\mathrm{P}<0.05)$. There was not any significant difference in the kidneys given Klangon and Sumber Bendo Porang tuber $(\mathrm{P}>0.005)$ and the kidneys were given Sumber Baru Porang tuber powder was the highest at accumulation of calcium on kidneys.

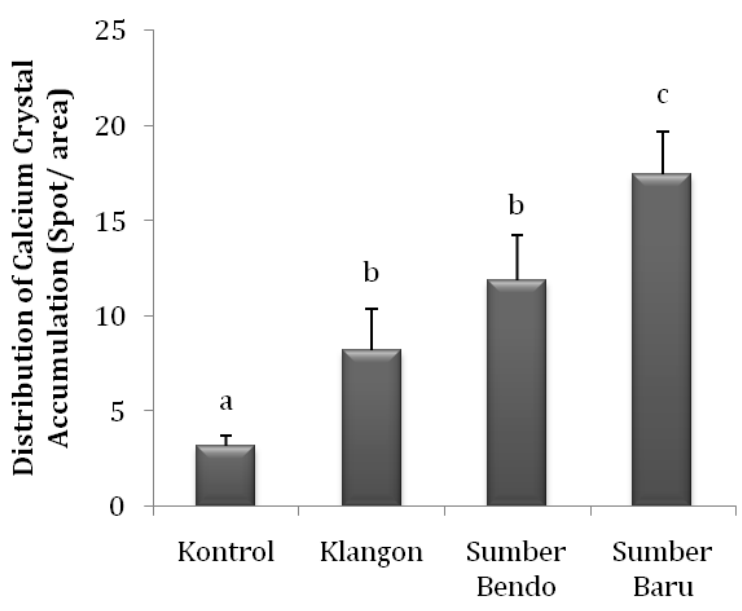

Figure 2. Distribution of calcium crystal accumulation in rat kidneys after supplemented with Porang tuber powder.

Consumption of calcium oxalate-contained food may cause calcium oxalate accumulation in the body, especially the kidneys [11]. Before 
entering the kidneys, calcium oxalate will first be absorbed by intestinal cells, taken by passive transport pathways in particular, and the go further through the paraselluler by the circulatory system. However, most of the calcium oxalate not absorbed by intestines will come out of the body through the feces [12]. When calcium oxalate enters the kidney, there is an increase in the activity of oxalate binding protein. Oxalate binding protein is a protein that plays a role in the nucleation process in the kidneys crystallization. Increase in the oxalate binding activity of this protein is affected by the amount of calcium oxalate in the kidneys. These circumstances would lead to the accumulation of calcium oxalate in the kidneys [8]. This condition generates interaction between oxalate and renal cells. The crystalisation process is caused by urine supersaturation having high amount of calcium, phosphate, and oxalate that will finally cause calcium oxalate crystal formation. Thus, the oxalate crystal will be bound to the renal tubulus cells and interaction between the two will bw generated [6]. Exposure to oxalate elicits changes in renal plasma membranes that can lead to cell injury and the retribution of membrane phosphatidyl serine from the inner layer of the cell to the cell surface. This condition promotes crystal attachment to the renal cells. In another condition, calcium oxalate crystal can be taken up by the kidney cells through an endocytosis process. Oxalate interacts with renal ephithelial cells, leading to membrane changes, including endocytosis of crystal and retribution of phosphatidyl serine which can generate some lipid signaling. This lipid signaling will be responed by mithocondria, shown by an increase of ROS and cythochrome C, an increase of GSH activity, and a decrease in potential membranes. The net response to oxalate exposure can be cell death or apoptosis. The dead cell debris have been instrumental in the nucleation process of crystals in the kidney. When the crystal has undergone nucleation, then the crystal will grow. When solid particles, as a result of nucleation process, reside in a urinary track and desist in that track, the particles can grow and become stone in a big size. Calcium oxalate crystals can accumulate in all parts of the kidney and accumulate as a result of crystal grow [13]. The different of crystal accumulation on rats kidneys by the administration of different Porang tuber because of the different calcium oxalate that contain in each tuber. the production of calcium oxalate by plant is depend on her environment condition [14].

\section{CONCLUSION}

The result of the study showed that consumption of tuber Porang powder induced calcium crystal accumulation in rat kidneys. The use of tuber Porang powder from different locations was found to generate different impacts on the accumulation of calcium crystal. The lowest calcium crystal accumulation in kidneys was the ones given Klangon Porang powder, which was equal to $8.19 \pm 2.17 \mathrm{spot} /$ area.

\section{ACKNOWLEDGEMENT}

This work was supported by Student Grant IMHERE for under graduate program and Research Grant I-MHERE on behalf of Dr. Sri Rahayu, M.Kes.

\section{REFERENCES}

1. Francheschi VR, Nakata PA (2005) Calcium oxalate in plants: formation and function. Annual Review of Plant Biology. 56: 41-71.

2. Sufiani S (1993) Iles-iles (Amorphophallus), jenis, syarat tumbuh, budidaya, dan standar mutu ekspor. Media Komunikasi Penelitian dan Pengembanagan Tanaman Industri. 12: 11-15.

3. Prychid CJ, Jabaily RS, Rudal PJ (2008) Cellular Ultrastructure and Crystal Development in Amorphophallus (Araceae). Annuals of Botany. 101: 983-995.

4. Honetman T, Cao L, Jonassen J, Scheid C, (2000) Oxalate-induced ceramide accumulation in madin-darby canine kidney and LLC PK1 cell. Kidney International. 57: 2403-2411.

5. Selvam R, (2003) Calcium oxalate stone disease: role of lipid peroxidation and antioxidants. Urol Res. 30: 35-47.

6. Tsujihata M, (2007) Mechanism of calcium oxalate renal stone formation and renal tubular injury. International Journal of Urology. 15: 115120.

7. Khan SR (1995) Calcium oxalate crystal interaction with renal tubular epithelium, mechanism of crystal adhesion and its impact on stone development. Urol Res. 23: 71-79.

8. Kalaiselvi P, Selvam R (2003) Oxalate binding protein in calcium oxalate nephrolithiasis. Urol Res. 31: 242-256.

9. Clark G (1973) Staining procedures 3rd edition. Williams and Wilkins. Baltimore.

10. Khan SR, Thamiselvan S (2000), Nephrolithiasis: A consequence of renal ephitelian cell exposure to oxalate and calcium oxalate. Mol Urol. 4: 305312.

11. Jansen PCM, Wetsphal E, Wulijarni-Soetjipto $H$ (1996) Plant resoursces of south asia 9: Plants 
yielding non-seed carbohydrates. Prosea Foundation. Bogor.

12. Henes DA, Weaver CM, Heaney RP, Weatsney M (1999) Absorpsion of calcium oxalate does not require dissociation in rats. The Journal of Nutrition. 170-174.

13. Scheid CR, Cao L, Honeyman T, Jonassen JA (2004) How elevated oxalate can promote kidney stone disease: changes at the surface and in the cytosol of renal cells that promote crystal adherence and growth. Frontiers in Biosciense. 9: 797-808.

14. Paiva EAS and Machado SR (2005) Role of intermediary cells in peltodon radicans (lamiaceae) in the transfer of calcium and formation of calcium oxalate crystals. Exegatic International Journal. 48: 147-153 